\title{
Library Security and the Law
}

\begin{abstract}
Thefts of library material are primarily covered under general provisions of the criminal code. A recent law in Virginia does provide separate consideration for library theft and introduces the relatively new legal concepts from shoplifting legislation. Basic elements in such legislation are discussed: willful concealment, detention of suspect, and immunity from civil liability. The law of arrest, an adjunct to such legislation, is also considered. The article concludes with a model law relating to library theft drafted by the author.
\end{abstract}

\begin{abstract}
$\mathbf{I}_{\mathrm{N}}$ GENERAL, LAWS RELATING TO LIBRARY SECURITY fall into two principal categories. One type of law makes it a misdemeanor to mutilate or destroy library materials. A good example of this is the Indiana statute enacted in 1961 which reads as follows:

Any person who wilfully or maliciously writes upon, cuts, tears, defaces, disfigures, soils, obliterates, breaks or destroys any book, pamphlet, document, newspaper, periodical, file card, map, chart, picture, portrait, engraving, statue, coin, medal, equipment, specimen, recording, film, or other work of literature or object of art belonging to or in the care of a library, gallery, museum, collection, exhibition or belonging to or in the care of any department or office of the state or local government or belonging to or in the care of a library, gallery, museum, collection or exhibition which belongs
\end{abstract}

Alex Ladenson is special executive assistant to the board of directors, Chicago Public Library. This article is based on an address given at the ALA Conference in July 1976 in a program, "Stealing the American Heritage: The Theft of Manuscripts from Libraries and Archives," presented by the Manuscripts Collections Committee, ACRL Rare Books and Manuscripts Section. to any incorporated college or university or which belongs to any institution devoted to educational, scientific, literary, artistic, historical or charitable purposes, without making restitution for the property damaged or destroyed to the owner or custodian shall be guilty of a misdemeanor and upon conviction shall be liable to a fine of not more than fifty dollars $(\$ 50.00)$ or imprisonment for not more than ten (10) days. (Burns Annotated Indiana Statutes, Sec. 41-1102.)

It is quite clear that this law is also intended to protect archival materials as well as art and museum objects, and a thorough examination of the laws relating to archival administration and records management reveals that archival security is closely linked with library security. This is understandable, not only because there exists a close relationship between archives and libraries, but also because in many jurisdictions the state library serves as the state archival agency.

The second type of general law makes it a misdemeanor to fail to return library materials that have been retained after the expiration of the loan period. These two general laws are on the statute books of most states in one form or another. In some jurisdictions, however, 
such as Arkansas, Illinois, and Oklahoma, the public library act authorizes the corporate authorities of a municipality to provide by ordinance suitable penalties for the misuse or destruction of library materials. In other jurisdictions, such as Florida and Tennessee, the public library act empowers the library board to fix and impose by general rules penalties for loss or injury to library property.

\section{Theft of Library Material}

In addition to these two basic types of laws, the actual theft of library materials in most states is covered under the general provisions of the criminal code. In Illinois, for example, the theft of property (which includes library materials) not exceeding $\$ 150$ in value is a Class A misdemeanor which carries a penalty of less than one year in a penal institution other than a penitentiary. The theft of property exceeding $\$ 150$ in value is a Class 3 felony with a penalty of one to ten years in a penitentiary.

In the field of public records, there are laws at both the state and federal levels that make it a crime to conceal, remove, mutilate, or destroy public records. This prohibition extends to persons who have legal custody of public records, and in general this offense is classed as a felony.

Another law which should be mentioned is a California statute enacted in 1923 which makes it a crime for dealers and collectors to purchase any "book, manuscript, map, chart, or other work of literature, belonging to, and bearing any mark or indicia of ownership by a public or incorporated library, college or university, without ascertaining by diligent inquiry that the person selling or delivering the same has a legal right to do so."

The most recent and perhaps most innovative legal enactment in the field of library security is the Virginia Act of 1975. The Virginia law contains two unique provisions, the first of which reads as follows:

Whoever, without authority, with the intention of converting to his own or another's use, willfully conceals a book or other library property, while still on the premises of such library, or willfully or without authority removes any book or other property from any of the above libraries or collections shall be deemed guilty of larceny thereof, and upon conviction thereof shall be punished as provided by law. Proof of the willful concealment of such book or other library property while still on the premises of such library shall be prima facie evidence of intent to commit larceny thereof. (Code of Virginia, Sec. 42. 1-73.)

What makes this provision unique is that the willful concealment of a book or other library property is declared to be a separate and distinct crime. Moreover, proof of the willful concealment of a book or other library property constitutes prima facie evidence of intent to commit larceny. This means that a person who conceals a book with the intention of converting it to his or her own use, and is apprehended, will be presumed to have committed larceny. The burden of proof thus shifts to the offender to show that he or she did not intend to commit larceny.

The second unique provision in the Virginia law is the following:

A library or agent or employee of the library causing the arrest of any person pursuant to the provision of 42. 1-73, shall not be held civilly liable for unlawful detention, slander, malicious prosecution, false imprisonment, false arrest, or assault and battery of the person so arrested, whether such arrest takes place on the premises of the library or after close pursuit from such premises by such agent or employee; provided that, in causing the arrest of such person, the library or agent or employee of the library had at the time of such arrest probable cause to believe that the person committed will- 


\section{Library Security o the Law / 111}

ful concealment of books or other library property. (Code of Virginia, Sec. 42. 1-73.1.)

This act was drafted by the legal counsel of the University of Virginia at the request of the university library and was supported by the Virginia State Library and the Virginia Library Association. In essence the Virginia Act of 1975 is an adaptation of the Virginia shoplifting statute of 1958 . On the face of it the law appears to be a highly desirable measure. The legislative intent is clear. It is designed to combat library and archival theft by providing a legàl mechanism for facilitating the apprehension of an offender and to afford the same legal protection to librarians and archivists that the Virginia Code provides to merchants in the protection of their merchandise from shoplifters. It appears to be most useful in a situation where the theft is actually observed by a member of the institution's staff. The right to detain an offender for questioning or arrest, without fear of adverse legal consequences, is an important tool that the new statute provides.

Because the Virginia act introduces a relatively new legal concept which is commonly referred to as the shoplifting legislation, it is important that we turn to an analysis and critique of the underlying elements of this new legal development.

\section{The Common LAw}

Under the common law the owner of property could use reasonable force to recover goods that had been unlawfully taken. If, however, an innocent person was accosted, detained, questioned, searched, or arrested, the owner of the property was civilly liable for wrongful conduct. Thus the innocent person could sue for damages in an action for false imprisonment, false arrest, assault and battery, malicious prosecution, or defamation, depending on the circumstances of the case.

\section{SHOPLIFTING LegisLATION}

Because the common law did not provide retail merchants with sufficient protection against pilfering, and because the incidence of shoplifting increased drastically in the period following World War II, shoplifting statutes have been enacted in forty-four states and attempt to provide retail merchants with additional protection not afforded by the common law. The laws vary considerably from state to state, but taken as a whole the shoplifting legislation contains three basic elements:

1. It defines the crime of shoplifting as the willful concealment of any merchandise with the intention of converting it to one's use.

2. It authorizes the merchant or an employee to detain the suspect, where there is probable cause to believe that the suspect has committed theft.

3. It provides the merchant with a legal defense in civil actions arising out of such detention.

The legal ramifications of these three basic elements may now be examined.

\section{Willful Concealment}

Before the passage of the shoplifting statutes, shoplifting was prosecuted under the general criminal laws involving larceny. It was not easy, however, to obtain convictions under the larceny laws because the evidence required to prove larceny was often not available in shoplifting cases. To assist merchants in bringing criminal charges against offenders caught pilfering, the new statutes in a number of states make shoplifting a separate and distinct crime by defining it as "willfully concealing any merchandise with the intention of converting it to one's use without payment to the owner."

Some of the statutes go even further and provide that the finding of goods concealed upon a person or his or her belongings is prima facie evidence of 
willful concealment. The effect of this latter provision is that if the finding of goods concealed upon a person is declared to be prima facie evidence of willful concealment, then the intent to convert to one's own use does not have to be proven by the prosecution. The burden of proof thus shifts to the accused persons to show beyond a reasonable doubt that they did not intend to convert the goods to their own use, or to put it more directly, they did not intend to steal the goods.

The Virginia act of 1975 has adapted both of these provisions. In the first place, it makes a person who willfully conceals a book or other library property with the intention of converting it to his or her own use guilty of larceny. It also provides that proof of the willful concealment of such book or other library property while still on the premises of such library shall be prima facie evidence of intent to commit larceny.

These two provisions are highly significant because they prevent suspected thieves from claiming that they forgot to return the manuscript or book, or that they meant to have the material charged out, or to offer some other fabricated excuse.

\section{Detention of Suspect}

The second basic element of the shoplifting legislation provides authorization to detain a suspect when a merchant has probable cause to believe that the suspect has committed the crime of shoplifting. Here we encounter some constitutional prohibitions that must be scrupulously observed. There are two opposing legal principles present. On the one hand is the right of property, and on the other stands the right of the individual to be free and unmolested. We are dealing in an area of law that is extremely sensitive. Freedom from false arrest, freedom from unlawful search, and the right of privacy are all involved here. What we need, of course, is to strike a delicate balance.

But balancing property rights with personal rights is not a simple task. The Supreme Court of Mississippi in the case of J. C. Penney Co. v. Cox (246 Miss. 1) stated this dilemma as follows:

Shoplifting is not uncommon in the merchandising field, and some rules and regulations must exist for the protection of the merchant; public policy makes it necessary to provide for the protection of merchants against shoplifting. . . The protection of merchants from shoplifters [however] would not under any circumstances be justification for the usurpation of the rights and freedoms of the individual citizens of this state and country. The evils of shoplifting are probably great in this country at this time. [Yet], taking care of the interests of the merchants would not justify giving them complete power and authority to infringe upon the rights of their customers and allow the merchants, without regard to the feelings of the customers, to require them to submit to certain humiliations and disgrace of being indiscriminately accused of stealing or to be subjected to search upon the mere whim of the merchant or his employees.

\section{Probable Cause}

Now then, how does the shoplifting legislation resolve this dilemma? First, in many states the shoplifting statutes provide that the merchant must have probable cause to believe that the person committed the crime before he or she can detain the individual. The term "probable cause" constitutes a dangerous pitfall for the merchant.

The courts have denied the existence of probable cause in such cases, for example, where a suspect merely placed his hand under his shirt and walked off at a rapid pace (Banks v. Food Town, 98 So. $2 \mathrm{~d} 719$ ) or where another customer merely reported his belief that the suspect had been shoplifting ( $J$. C . Penney Co. v. Cox, 246 Miss. 1). If, 
however, the missing items are actually found upon the suspect (Delp v. Zapp's Drug \& Variety Stores, 238 Ore. 538) or if an employee reports having actually seen the items being concealed by the suspect (Gibson v. J. C. Penney Co., 165 Cal. App. 2d 640), then the courts have held that there is probable cause.

The test of what constitutes probable cause cannot be determined with mathematical precision. The courts have generally relied on the so-called "reasonable man" doctrine. Thus probable cause has been defined as a suspicion founded upon circumstances sufficiently strong to warrant a reasonable man to believe that the charge is true (Sebastian v. Crowley, 38 Cal. App. 2d 194).

\section{Detention for a Particular Purpose}

In order to satisfy the constitutional mandates of freedom guaranteed to all citizens, there are other limitations placed on the merchant who seeks to detain a suspected shoplifter. In order to sanction the invasion of personal liberties, the law requires that the detention of a suspect be for a particular purpose. For this reason most shoplifting statutes provide that the detention may be only for specified purposes. Illinois and Oklahoma permit the widest scope of purposes.

In Illinois the detention is permissible for the following purposes:

(a) To request identification;

(b) To verify such identification;

(c) To make reasonable inquiry as to whether such person has in his possession unpurchased merchandise and to make reasonable investigation of the ownership of such merchandise;

(d) To inform a peace officer of the detention of the person and surrender that person to the custody of a peace officer;

(e) In the case of a minor, to inform a peace officer, the parents, guardian or other private person interested in the welfare of that minor of this detention and to surrender custody of such minor to such person. (Illinois Revised Statutes, Chapter 38, Sec. 16 A-5.)

The Illinois statute also provides that a detention, as permitted above, does not constitute an arrest or an unlawful restraint as defined elsewhere in the criminal code. In Oklahoma the detention is for the purpose of effecting a recovery, searching the suspect, and conducting an investigation. In these jurisdictions, the merchant can undoubtedly question and search a suspect, whether or not the merchant believes that the suspect still has the merchandise in his or her possession. In this connection it is interesting to note that the Ohio statute specifically prohibits a merchant from making a search.

In some states the statute merely allows the merchant to detain a suspect for the purpose of effecting a recovery of the goods. Under this statutory language it has been held that the merchant apparently is authorized to search a suspect or to question the suspect concerning the possession of merchandise.

In other states the statute authorizes the merchant to detain a suspect only to investigate ownership or to question and investigate ownership. This type of statute would permit the merchant to question suspects as to whether they possess the goods, where they got them, and whether they paid for them. It is not clear, however, as to whether the merchant has the right to search the suspect without exceeding this authority.

In some states the statute provides that the merchant may detain a suspect to interrogate or to question concerning guilt or ownership, and, finally, in a few states a merchant may detain a suspect for the sole purpose of delivering the suspect to a police officer. Here it appears to be quite clear that, under this language, the merchant cannot question nor search the suspect. 


\section{Manner of Detention}

Another limitation on the merchant's authority relates to the manner in which the detention is exercised. Most statutes provide that the detention must be in a reasonable manner and for a reasonable length of time. This requirement means that interrogation conducted in an insulting and humiliating fashion may be held to be unreasonable. A detention which is made unnecessarily public may also be held to be unreasonable.

The detention should be carried out in a private office or area whenever possible. In a number of states the statutes require that the detention take place upon the premises of the merchant or in the immediate vicinity thereof, which would include the parking lot. A question of great concern involved in the manner of detention is the degree of force that the merchant may apply. It is possible that the courts will allow the merchant to use the same degree of force that the common law permits to recover personal property.

Shoplifting statutes also provide that the detention must be exercised within a reasonable length of time. Now then, what constitutes a reasonable length of time? A number of states fix a specific time limit. The West Virginia statute, for example, sets a time limit of thirty minutes. In Indiana the time limit is one hour. In other jurisdictions it is the time required to question the suspect or the time required for the arrival of the police. It should also be observed that the suspect must be detained immediately after it is believed the individual committed the offense. If suspects are permitted to leave the premises, they cannot be detained should they return on a subsequent day.

One final limitation relates to the question of who is permitted to detain the suspect. Most statutes grant the privilege to the merchant, merchant's employee, or a police officer.

\section{Immunity from Civil Liability}

The third basic element of the shoplifting legislation is a provision granting the merchant immunity from civil liability for actions arising out of the detention of a suspect. Some statutes merely authorize the detention but do not specifically grant immunity from civil liability. This means that some form of immunity is implied, and the courts must determine whether the statute provides by implication a defense in some types of civil action and not in others, or that the statute is intended to provide a defense in all actions. Then there are some statutes which grant immunity from certain named civil actions such as false arrest, false imprisonment, and others.

It has been argued that the weakness of this approach is that it would be possible for an ingenious plaintiff to bring an action in a form which is not covered by the statute. Finally, some statutes grant immunity from all civil and criminal actions. This approach leaves a wronged individual completely without any legal remedy. It is for this reason that most jurisdictions prefer to extend the defense only to certain classes of action. The actions for which immunity is granted are chiefly false imprisonment, false arrest, unlawful detention, assault, battery, slander, libel, and malicious prosecution.

\section{The LAW OF ARREST}

An important adjunct to the shoplifting statute is the law of arrest. Under the common law neither police officers nor private citizens are permitted to make an arrest for a misdemeanor without a warrant if it does not involve a breach of the peace, even though committed in their presence. With respect to a felony, a police officer or a private citizen may arrest without a warrant a person who is in the act of committing such an offense. A police officer may also arrest a person without a warrant who 
is suspected of having committed a felony, providing there is reasonable ground to believe that the suspect is guilty of the offense. A private citizen, however, may not make such an arrest.

To modify and expand the common law rules relating to arrest, a number of states, by statutory enactments, have increased the power of police officers to arrest without a warrant where shoplifters are involved. Under these laws a police officer is permitted to make an arrest without a warrant where there is reasonable ground or probable cause to believe that the crime of shoplifting has been committed or attempted, even though not in the officer's presence. West Virginia has broadened the power of a private citizen to make an arrest for shoplifting by declaring shoplifting to be a breach of the peace, thereby allowing a merchant to make an arrest if the crime is committed in his or her presence.

In a note in the Nebraska Law Review two further constitutional questions involving the Nebraska shoplifting statute are raised. ${ }^{1}$ The first question is whether the goods seized by the merchant may be admitted into evidence in a criminal prosecution of the shoplifting suspect. The question is complicated and involves the Fourth Amendment to the U.S. Constitution which sets forth the requirements for a lawful search and seizure. The second constitutional question is whether the shoplifting suspect is entitled to legal counsel during the detention and questioning period. In Escobedo v. Illinois (378 U.S. 478) the United States Supreme Court held that an individual is entitled to counsel during an accusatory interrogation where a confession is obtained. This decision was further strengthened in the case of Miranda v. Arizona (384 U.S. 436).

However, in a recent case, State v. Bolan (27 Ohio St.2d 15), involving a shoplifting suspect, the Ohio Supreme

\section{Court rendered the following opinion:}

We do conclude, however, that where $\ldots$ an employee of a merchant has detained a person whom he has probable cause to believe has unlawfully taken items for sale by the mercantile establishment, an admission or confession made during such detention is not rendered inadmissable by the failure of such employee to fully explain to such detained persons those constitutional rights set forth in Miranda v. Arizona.

The court went on to cite cases in other jurisdictions which held that detention and questioning by department security guards in connection with a shoplifting statute was held not to require "Miran$d a$ warnings."

\section{Conclusion}

It now remains for other states to consider following Virginia's pioneer effort in adapting the principles of the shoplifting statute to cover archival and library theft. Despite the limited applicability of the shoplifting statute, and despite the great care that must be exercised in not violating the constitutional rights of an individual, the shoplifting statute does provide additional protection not afforded by either the common law or other existing laws, both as a punitive force and as a deterrent measure.

In a society where law is fundamental, we have no alternative but to seek whatever legal remedies are available to correct wrongs that have been committed. Moreover, if theft from libraries and archives has reached alarming proportions, as Philip B. Mason has asserted in a recent article, ${ }^{2}$ then it is imperative to take all necessary measures to protect these institutions' resources. It is clear that the gravity of the problem calls for new legislation. In response to this need, this writer has drafted a model law relating to library theft which is printed below.

One final comment is offered: with 


\section{6 / College \& Research Libraries • March 1977}

respect to manuscripts and public records, more states should adopt the legal provision that libraries and archives may make facsimile reproductions of such materials and that the reproductions have the same force and effect as the original copies. This would make it possible for archives and libraries to refuse to make original copies of rare manuscripts and public records available to the public where a facsimile reproduction exists.

\section{A Model Law Relating TO LIBRARy THEFT}

\section{Sec. 1. Declaration of Policy}

Because of the rising incidence of library theft, libraries are suffering serious losses of irreplaceable books, manuscripts, and other resources. In order to preserve rare research materials for posterity, it is the policy of this state to provide libraries and their employees and agents with additional legal protection to insure greater security for their collections.

\section{Sec. 2. Crime of Library Theft}

A person is guilty of the crime of library theft when he willfully conceals on his person or among his belongings a book or other library materials while still on the premises of the library or willfully and without authority removes a book or other library materials from such library with the intention of converting them to his own use.

\section{Sec. 3. Presumptions}

A person who willfully conceals a book or other library materials on his person or among his belongings while still on the premises of the library or in the immediate vicinity thereof shall be prima facie presumed to have concealed the book or other library materials with the intention of converting them to his own use. If a book or other library materials are found concealed upon his person or among his belongings, it shall be prima facie evidence of willful concealment.

\section{Sec. 4. Detention}

A library or an employee or agent of a library that has probable cause to believe that a person has committed library theft may detain such person on the premises of the library or in the immediate vicinity thereof for the following purposes:

a) To conduct an investigation in a reasonable manner and within a reasonable length of time to determine whether such person has unlawfully concealed or removed a book or other library materials.

b) To inform a peace officer of the detention of the person and to surrender that person to the custody of a peace officer.

\section{Sec. 5. Exemption from Liability}

A library or an employee or agent of a library who detains or causes the arrest of any person pursuant to section 4 of this act shall not be held civilly or criminally liable for false arrest, false imprisonment, unlawful detention, assault, battery, slander, libel, or malicious prosecution of the person detained or arrested, provided that in detaining or causing the arrest of the person, the library or the employee or agent of the library had at the time of the detention or arrest probable cause to believe that the person committed the crime of library theft as defined in section 2 of this act.

Sec. 6. Arrest without Warrant by Peace Officer

Any peace officer may arrest without a warrant any person he has probable cause for believing has committed the crime of library theft as defined in section 2 of this act.

\section{Sec. 7. "Book or Other Library Materials" Defined}

The terms "book or other library materials" as used in this act include any book, plate, picture, photograph, engraving, painting, drawing, map, newspaper, magazine, pamphlet, broadside, manuscript, document, letter, public record, microform, sound recording, audiovisual materials in any format, magnetic or other tapes, electronic data processing records, artifacts, or other documentary, written, or printed materials, regardless of physical form or characteristics, belonging to, on loan to, or otherwise in the custody of the following: (1) any public library; (2) any library of an educational, historical or eleemosynary institution, organization, or society; (3) any museum; (4) any repository of public records. 


\section{Sec. 8. Penalties}

(Note: This section is reserved for the inclusion of a penalty provision for the crime of library theft which must be fixed in accordance with the general policy of each state.)

\section{Sec. 9. Library Theft: Construction}

This act shall be construed to be cumulative and supplemental to all other laws of the state of - and the crime herein defined and the presumptions herein created shall be in addition to previously existing crimes and presumptions provided by law.

Sec. 10. Copies of This Act to Be Publicly Displayed

A copy of this act shall be publicly displayed in the reading rooms of all libraries and other institutions covered by this measure.

\section{REFERENCES}

1. Stephen M. Joynt, "Nebraska's Anti-Shoplifting Statute," Nebraska Law Review 44: 681-89 (1965).

2. Philip P. Mason, "Archival Security: New Solutions to an Old Problem," American Archivist 38:477-92 (Oct. 1975).

\section{AdDitional ReFERENCES}

Thomas L. Kummer, "North Carolina Shoplifting Statute," Wake Forest Law Review 7: 683-88 (1971).

William J. Markstrom, "Legislation-Survey and Analysis of Criminal and Tort Aspects of Shoplifting Statutes," Michigan Law Review 58:429-55 (1960).

"The Merchant, the Shoplifter and the Law," Minnesota Law Review 55:825-69 (1971).

Robert W. Muren, "Shoplifting: Protection for Merchants in Wisconsin," Marquette Law Review 57:141-71 (1973).

"Shoplifting Law: Constitutional Ramifications of Merchant Detention Statutes," Hofstra Law Review 1:295-314 (Spring 1973). 